Personalidade Acadêmica Homenageada:

Raymundo Juliano Feitosa (Universidade Federal do Rio Grande do Norte - UFRN)

\title{
UM É POUCO, DOIS É BOM, TRÊS POUCOS SABEM: AS VISÕES JURÍDICAS DAS RELAÇÕES POLIAMOROSAS
}

\section{JÚLIA DUARTE DE FARIA}

Graduanda do curso de Direito Modalidade Integral - Escola Superior Dom Helder Câmara - Belo Horizonte - MG. E-mail: juliadfariabh@gmail.com.

\section{CAIO AUGUSTO SOUZA LARA}

Mestre e Doutor em Direito pela Faculdade de Direito da Universidade Federal de Minas Gerais - UFMG. Professor da Escola Superior Dom Helder Câmara. Pesquisador Associado ao Programa RECAJ-UFMG - Acesso à Justiça e Solução de Conflitos. Secretário de Comunicação do Conselho Nacional de Pesquisa e Pósgraduação em Direito - CONPEDI. Belo Horizonte-MG. E-mail: caiolarabh@yahoo.com.br.

\section{RESUMO}

O tema-problema da pesquisa que se desenvolve é o surgimento das formas de relações não monogâmicas e como elas são analisadas no âmbito jurídico brasileiro. De acordo com uma pesquisa da consultoria americana YouGouv feita em 2016, $17 \%$ dos participantes de 18 a 44 anos disseram ter tido permissões dos parceiros para ter relações com outras pessoas. O estudo declarou também que só $69 \%$ das mulheres e $52 \%$ dos homens acreditam que o tipo ideal de relacionamento é completamente monogâmico (TOLEDO; 2017). A pesquisa feita nos Estados Unidos serve para exemplificar as mudanças de pensamento que ocorrem na sociedade nos últimos anos. Junto com essas transformações internas, o modo das pessoas de se relacionar se transforma também gerando novos tipos de relacionamentos que antes eram considerados incabíveis no âmbito social. É essencial o debate e pesquisa 


\section{Personalidade Acadêmica Homenageada:}

Raymundo Juliano Feitosa (Universidade Federal do Rio Grande do Norte - UFRN)

acerca do poliamorismo, pouco discutido devido ao preconceito por parte da sociedade por ser uma construção familiar recente e muito diferente do conceito conservador de "Família Tradicional Brasileira" disseminado no senso comum e reafirmado com o Estatuto da Família (PL 6.583/2013). Vale ressaltar que os aderentes dessa forma de relacionamento se enquadram tanto quanto os monogâmicos na descrição prevista no código civil mudando somente quanto ao número de participantes. Considerando a dinamicidade dessas relações humanas fazse imprescindível a atualização do aparato estatal, principalmente o Direito de Família, para que este se adeque as novas realidades afetivas. É possível perceber também o motivo da importância do debate sobre elas e a adaptação dos aparatos legislativos, para que nenhum cidadão tenha seus direitos básicos garantidos pela constituição violados. O problema objeto da investigação científica proposta é: como o sistema jurídico brasileiro se posiciona diante das relações poliamorosas que cresceram nos últimos anos? A partir das reflexões preliminares sobre o tema, é possível perceber que apesar do Código Civil Brasileiro considerar união estável a relação de convivência entre homem e mulher, duradoura e a fim constituir família. Assim como em maio de 2011 o Supremo Tribunal Federal também passou a reconhecer a união estável homossexual assumindo os princípios fundamentais da Constituição da República que garantem a cidadania, a dignidade da pessoa humana assim como o compromisso do Estado brasileiro em promover o bem de todos, sem preconceitos de origem, raça, sexo, cor ou quaisquer outras formas de discriminação supõe-se que é possível e necessário a regularização do reconhecimento de uniões estáveis poli amorosas baseando nesses mesmos princípios. O objetivo geral do trabalho é analisar como são tomadas as decisões judiciais que se referem às relações afetivas poli amorosas. A pesquisa que se propõe pertence à vertente metodológica jurídicosociológica. No tocante ao tipo de investigação, foi escolhido, na classificação de Witker (1985) e Gustin (2010), o jurídico-projetivo. O raciocínio desenvolvido na pesquisa será predominantemente dialético. De acordo com a técnica de análise de conteúdo, afirma-se que se trata de uma pesquisa teórica o que será possível a partir da análise de conteúdo dos textos doutrinários, normas e demais dados colhidos na pesquisa. A partir do exposto, conclui-se que a não adaptação do sistema jurídico com 
Personalidade Acadêmica Homenageada:

Raymundo Juliano Feitosa (Universidade Federal do Rio Grande do Norte - UFRN)

relações ao poliamorismo fere diretamente os direitos básicos dos indivíduos garantidos pela Constituição da República de 1988. Tendo em vista que os aderentes desse tipo de compromisso estão de acordo com os fins estabelecidos pela união estável e o casamento visando à constituição de família, com direitos e deveres recíprocos com mutua lealdade, respeito, fidelidade, partilhando o domicilio, guarda, sustento e educação dos filhos e possuem os mesmos direitos dos cidadãos em relacionamentos monogâmicos.

PALAVRAS-CHAVE: Poliamor; Direito de Família; Casamento; União Estável.

\section{REFERÊNCIAS}

BRASIL. Código Civil. Disponível em: http://www.planalto.gov.br/ccivil_03/leis/2002/10406.htm. Acesso em: 26 maio 2019.

Constituição da República Federativa do Brasil de 1988. Disponível em: http://www.planalto.gov.br/ccivil_03/constituicao/constituicao.htm. Acesso em: 13 de maio 2019.

CASTRO, Carol; TOLEDO, Giuliana. Poliamor: Brasileiros apostam em diferentes formas de relacionamentos. Galileu - 7 de agosto de 2017. Disponível em: https://revistagalileu.globo.com/Revista/noticia/2017/09/poliamor-brasileirosapostam-em-diferentes-formas-de-relacionamentos.html. Acesso em: 10 de maio de 2019.

GUSTIN, Miracy Barbosa de Sousa; DIAS, Maria Tereza Fonseca. (Re)pensando a pesquisa jurídica: teoria e prática. 3ª̣. ed. Belo Horizonte: Del Rey, 2010.

MALMONGE, Luana Cristina. Poliamor: a quebra do paradigma da "Família Tradicional Brasileiro". Boletim Jurídico, Uberaba/MG, a. 13, Ed. 1441. 25 de maio de 2017. Disponível em: https://www.boletimjuridico.com.br/ doutrina/artigo/4204/poliamor-quebra-paradigma-familia-tradicional-brasileiro. Acesso em: 15 maio 2019.

MELO, Giovana Pelágio. Uniões Concomitantes. Universidade Católica Pontifícia (PUC/RS), Rio Grande do Sul, publicado em 2010. Disponível em: https://pt.scribd.com/document/249266713/giovana-melo-pdf. Acesso em: 11 maio de 2019. 
Personalidade Acadêmica Homenageada:

Raymundo Juliano Feitosa (Universidade Federal do Rio Grande do Norte - UFRN)

PERDOMO, Ariane; OLIVEIRA, Cristiane Catarina Fagundes de; CARLOS, Paula Pinhal de. Casamento entre pessoas do mesmo sexo: a fragmentação do Direito na decisão da Suprema Corte dos Estados Unidos. Revista Jurídica - Unicuritiba. Volume 1.2015 .2 Disponível em: http://revista.unicuritiba.edu.br/index.php/RevJur/article/view/1251. Acesso em: 20 de maio 2019.

WITKER, Jorge. Como elaborar una tesis en derecho: pautas metodológicas y técnicas para el estudiante o investigador del derecho. Madrid: Civitas, 1985. 